\title{
Editorial
}

\section{A Lexicon for Research on International Children's Rights in Troubled Times}

Human rights are under fire right across the world, not just from those who wish to avoid them but also from within the academic community, with many scholars challenging their value and efficacy. Informed criticism of this nature is healthy and welcome in any discipline. It is also not new to those who work in the field or pursue scholarship on children's rights: the question of whether children (can) have rights has been the subject of on-going discussion in legal theory (see, for example, Neil MacCormick's (1976) seminal article using children's rights as a "test case" for rights more generally) as have critiques of the content, meaning and efficacy of the human rights of children. However, I was recently told about a senior academic declaring to a post-doctoral researcher that he/she did not "believe" in children's rights as if the rights were somehow akin to the tooth fairy. A few years ago, a US scholar told me that he/she was a "parentalist" in much the same vein - a denial that children could and should be rights-holders. While that, of course, ignores the legal facts (and the public commitment of every United Nations member state, including the United States which has ratified two of the CRC's Optional Protocols), it is indicative of a wider problem: it appears to be perfectly acceptable to deny that children are, should or can be rights-holders when there are very few who would publicly assert that they do not "believe" in human rights. The problem for child rights advocates and the academy community, as I see it, is that the reluctance of some to accept the notion that children have rights has generated a revised or alternative lexicon for talking about children's rights that is increasingly problematic. In short, child rights discourse is being substituted, truncated and diluted to a status that I have previously dubbed, child rights "lite" (Lundy, 2014). Discourses of children's rights have emerged that have the potential to undermine not just practice but scholarship and I am taking the opportunity 
offered by this editorial to set out my perspective on what a child lens or approach is not.

A child rights lens is not pity. The Journal's Editor Emeritus, Michael Freeman, has consistently emphasised that rights are not about pity or charity, observing that rights are not mere gifts or favour for which gratitude is the sole fitting response. A right is something that can be demanded or insisted upon without embarrassment or shame (Freeman, 2001). While this is, of course, true for all human rights, children are especially prone to be the recipients of charitable responses. That is not necessarily or always a bad thing: the early child rights movement was established as a charitable response to child suffering in the aftermath of the First World War by Eglantyne Jebb and others. However, while the League of Nations' 1924 Declaration of Children's Rights was a phenomenal achievement in its time, the language used in it (e.g. 'the waif must be sheltered and succoured') is a far cry from a modern child rights approach. That said, even now, the portrayal, and some would argue exploitation, of children's suffering to garner pity in order to fund charitable responses to need is on-going. There is a growing body of material critiquing practices such as "sharenting" from the perspective of children's rights to privacy and their best interests yet little that uses the framework to question the use of images of destitute or dying children for fund-raising - sometimes to raise funding for services (such as institutional care) that are problematic from a child rights perspective. That is an area that could benefit from academic research with funders, donors and children themselves through a children's rights lens.

A child rights lens is not (just) protection. Protection has always been at the core of both a human and not just a child rights approach: the UN Declaration on Human Rights and the UN Declaration on the Rights of the Child (1959) both contain a panoply of rights that are about protecting humans from harm. The Convention on the Rights of the Child (CRC) recognised that children require bespoke protections given the fact that they are still developing and may be more vulnerable to harm(s) due to their size and/or lack of power. From drugs to sexual abuse and exploitation, working children and children recruited as soldiers, the Convention is replete with human rights for children that fall under the category of "protection". However, one of the distinctive and most crucial dimensions of a modern child rights lens, established in the Convention on the Rights of the Child, is that it does not limit children's rights to protection; It recognises that participation rights are just as, if not more, fundamental, in a child rights approach. In fact, I have argued that the more the child is in danger of harm, the more important it is that we recognise their agency and capacity for self-determination, arguing that 'vulnerability should not eclipse agency' (Lundy, 2018). This is especially true when children have 
been denied the most basic form of that - their freedom - for example, when they are victims of modern slavery, economic or sexual exploitation or are deprived of their liberty. The tendency in such instances is for responses to be dominated by a desire to protect. In the academic field, that can manifest itself in a focus on documenting the suffering and breaches of rights at the expense of looking for data that may show children being enabled or enabling themselves to survive in the most challenging of circumstances. For example, in a recent consultation with children who had been deprived of their liberty as part of the 2019 UN Global Study on Children Deprived of their Liberty, we were struck by how, even in the midst of some horrendous experiences, many children spoke of their aspirations, demonstrated resilience and resistance and/or gave views that do not always sit comfortably with traditional child rights approaches (including some, for instance, being positive about the impact of the detention). When we, as researchers, give an account of these experiences, we are bound to tell all of their "stories", not just the elements that evoke the type of pity discussed above to align with adults' perspectives or a desire to use the data to support a particular type of child rights advocacy (one that does not prioritise or accurately represent children's own perspectives).

A child rights lens is not (just) participation. The CRC was a landmark document - the first to underscore the fact that children, as rights holders, also enjoy a full range of civil and political rights, Article 12 in particular, became the hero of this radical children's rights approach, one that has appealed to the research community to inform, or least justify, participatory research with children. There has been a massive increase in research methods citing Article 12 and that, of course, is to be welcomed. Much of my own research falls in this category and, with Lesley Emerson, have argued that child participation is core to children's rights-based research (Lundy and McEvoy (Emerson), 2012). However, we also stressed the importance of locating any research within a broader package of substantive rights. Participation on its own does not equate to children's rights and talking to children in research does not by itself make a study a child rights research project. There can be a tendency in research with children, and in some children's rights discourse, to equate all of children's rights to child "voice", a term that is not only problematic in itself (Lundy, 2007) but ignores the rest of the child rights package, not least the other participatory rights (e.g. to freedom of expression, assembly and information) all of which are currently very much to the fore as Greta Thunberg and many others are claiming and exercising their rights without any need for adults to "involve" them in decision-making. Article 12 is important but not the only piece of the puzzle and its sometimes exaggerated status not only limits but also, in my view, diminishes the field of scholarship. 
A child rights lens is not a number of proxies. In recent years, a variety of substitutes have emerged that I would suggest amount to a partial or muted version of a children's rights approach. The first of these is in fact not an alternative discourse but an abbreviated version of the CRC itself - the so-called four general principles. In 2017, Karl Hanson and I published an article in this Journal in which we detail and analyse the rise and use of the four general principles. One of our conclusions was as follows: 'these four Articles, packaged as a set, constitute accessible shorthand for the child rights project as a whole. The sum is, to some extent, greater than the parts. But that is both good and bad since the "recognisability" and significance attached to these four Articles is not only legally and logically unsustainable but can distort and detract from the implementation and monitoring of the CRC as a whole' (Hanson and Lundy, 2017). A children's rights lens is not (just) the four general principles or indeed a smaller subset of these (with Articles 12 and 3 the most commonly used and cited).

A child rights approach is not the same as child well-being. In 2011 I was asked to probe the relationship between child rights and child well-being in a compendium focused on the latter. It seemed to me then, and still does, that the concepts of children's rights and children's well-being are being routinely "twinned" even though they are distinctive paradigms with different histories, rationales and indeed substance. I concluded as follows: 'References to the CRC in discussion about well-being are sometimes very loose or inaccurate, seemingly deployed as an international policy backdrop or to give pseudo-legal legitimacy to existing well-being approaches rather than indicative of any real attempt to engage with the CRC and its reconceptualization of the child as a holder of rights' (Lundy, 2014). The same can hold true in research with child rights often reduced to two well-being indicators (knowledge of rights and participation) - another type of contraction. In the chapter, I suggested that the child rights academic community could benefit from the significant expertise in measurement in child well-being scholarship and we are beginning to see more work in this field (e.g. Huynh and Stewart-Tufescu (2019) in the last issue). However, we need to ensure that the terms "children's rights" and "children's well-being" are not used interchangeably and that, when research addresses both, it does so in way that does not misrepresent or dilute children's rights.

And finally, a child rights lens is not the same as the Sustainable Development Goals (SDGs). The SDGs are a welcome and important device for encouraging governments to make better provision for children and adults across the world. They should provide a way of delivering on some children's rights commitments but they are not the same thing, in spite of a conscious and welcome attempt to make them more rights-based than their predecessors, the 
Millennium Development Goals. The SDGs cover only a portion of children's human rights and only a portion of the content of those same rights. A good example is Goal 4, equal access to quality education, which covers a small element of what is included in Articles 28 and 29 of the UNCRC. The SDGs are also a different framework: one that relies on goodwill and aspiration rather than legal obligation. The clue is in the nomenclature - "Sustainable Development Goals" are very different from "Immediate Rights Entitlements". We would welcome more research that explores the scope and implementation of the SDGS from a critical children's rights lens.

These are not the only ways in which children's rights discourse gets substituted or diluted. Ann Quennerstedt (2010) has previously questioned the way in which the so-called " 3 Ps" framework is used instead of the normal human rights discourse of civil, political, economic and social rights. Another common approach is to "balance" children's rights out by partnering them with children's responsibilities, an issue discussed in depth in a previous issue of the Journal by Harry Shier (2018). Debates about the purpose, classification, content and value of children's rights must continue and this Journal has a proud history of providing a public space for informed commentary and analysis of this kind. For example, we recently published an article that contributes to the debate about whether children can have rights from the perspective of moral philosophy (Giesinger, 2019). In this issue we have a series of papers that look at the implementation of children's rights across a spectrum of issues. We will not publish material on the Convention on the Rights of the Child that denies its existence or distorts it. Nor will we accept papers that are about issues that are related to children's rights but are not approached from a child rights lens at all or from one that is incomplete. This editorial is offered as a way of giving the Journal's authors and readership (and indeed the wider children's rights community) a sense of what a child rights lens is and is not and is, of course, open to expansion and discussion. Going forward in this continuing cold climate for children's rights, The International Journal of Children's Rights welcomes high quality papers that contribute to the field, exploring, explaining and critiquing the theories as well as the rights themselves and their implementation. The on-going resistance to children's rights, evidenced by the reluctance to call them what they are or to use them in their entirety, must be met with informed responses by the research community as we interrogate the rights themselves, their efficacy and their value. This applies as much to the scholarship as to the practice of children's rights. Moving on from the 3oth anniversary of the UNCRC, The International Journal of Children's Rights will provide a dedicated space for just such substantive but informed critique and analysis. This is not the only journal that publishes research on children's rights but it is the only 
international journal that only publishes research on international children's rights and it will continue to make this a priority.

\section{Acknowledgement}

I am grateful, as always, to the following for their helpful comments on earlier drafts of this editorial: Professor Priscilla Alderson, Professor Ursula Kilkelly, Dr. Gerison Lansdown, Dr. Harry Shier, Professor John Tobin, Margaret Tuite and, of course, my colleague and joint Editor in Chief, Professor Helen Stalford.

\section{Laura Lundy}

October 2019

\section{References}

Giesinger, J. (2019), "Children, Rights, and Powers", The International Journal of Children's Rights, 27(2), 251-265.

Hanson, K. and Lundy, L. (2017), "Does Exactly What it Says on the Tin?: A Critical Analysis and Alternative Conceptualisation of the So-called 'General Principles' of the Convention on the Rights of the Child", The International Journal of Children's Rights, 25(2), 285-306.

Huynh, E. and Stewart-Tufescu, A. (2019), "Exploring the Everyday Lives of Children in Winnipeg, Canada: A Qualitative Investigation of Children's Understanding of Well-being and Rights", The InternationalJournal of Children's Rights, 27(3), 545-561.

Lundy, L. (2007), "'Voice'is not enough: conceptualising Article 12 of the United Nations Convention on the Rights of the Child", British educational research journal, 33(6), 927-942.

Lundy, L. and McEvoy, L. (2012), "Children's rights and research processes: Assisting children to (in) formed views", Childhood, 19(1), 129-144.

Lundy, L. and McEvoy, L. (2012), "What Constitutes a 'Rights-Based' Approach?" in Diduck, Peleg (eds.), Law and childhood studies: Current legal issues, 14, 75.

Lundy, L. (2014), "United Nations Convention on the Rights of the Child and Child well-being", in Ben-Arieh, Asher, Ferran Casas, Ivar Frønes, and Jill E. Korbin, (eds.), Handbook of child well-being: Theories, methods and policies in global perspective. New York, NY, USA: Springer, 2014.

Lundy, L. (2018), European Forum for the Child. Proceedings available at: https:// europa.eu/newsroom/events/11th-european-forum-rights-child-children-deprived -their-liberty-and-alternatives-detention_en. 
MacCormick, N. (1976), "Children's Rights: A test-case for Theories of Right”, ARSP: Archiv für Rechts-und Sozialphilosophie/Archives for Philosophy of Law and Social Philosophy, 305-317.

Quennerstedt, A. (2010), “Children, But Not Really Humans? Critical Reflections on the Hampering Effect of the ' 3 p's',. The International Journal of Children's Rights, 18(4), 619-635.

Shier, H. (2018), “Towards a New Improved Pedagogy of 'Children's Rights and Responsibilities", The International Journal of Children's Rights, 26(4), 761-780. 